\title{
Quality of Public Spaces Data Evaluation
}

\section{Vyhodnocování dat o kvalitě veřejných prostranství}

Pavla Kilnarová, xakilnarova@fa.vutbr.cz

Ústav urbanismu, Fakulta architektury, Vysoké učení technické v Brně školitel: doc. Ing. arch. Gabriel Kopáčik, Dr.

\begin{abstract}
The way of the evaluating of a data from the survey for the quality of public spaces and its display can influence the interpretation of the conclusion. Currently, data collection takes place in two basic ways - from publicly available databases and in situ observations. This article describes a methodology for presenting and evaluating data acquired for this purpose. The contribution of the presented methodology is demonstrated on the case study of the square Jakubské náměstí in Brno, including the determination of the boundary conditions of individual imaging methods.
\end{abstract}

KEYWORDS: Urban spaces; quality; assessment; displaying; presentation

\begin{abstract}
ABSTRAKT: Způsob zobrazení vyhodnocovaných dat z průzkumu k hodnocení kvality veřejných prostranství může ovlivnit interpretaci závěru. V současné době probíhá sběr dat dvěma základními způsoby - z veřejně dostupných databází a pozorováním in situ. Tento článek popisuje metodiku prezentace a vyhodnocování dat pořízených za tímto účelem. Přínos předložené metodiky je demonstrován na př́ípadové studii zkoumaného Jakubského náměstí ve městě Brně, včetně stanovení okrajových podmínek jednotlivých zobrazovacích metod.
\end{abstract}

KLÍČOVÁ SLOVA: Veřejná prostranství; kvalita; hodnocení; zobrazování; prezentace 


\section{Úvod}

Veřejná prostranství a jejich kvalita jsou posuzovány $\mathrm{v}$ mnohých studiích, které na problém nahlížejí z hlediska různých kritérií. Zpracování velkého objemu dat a jejich srozumitelná interpretace jsou nutnými procesy, kterým by autoři měli věnovat pozornost. $\mathrm{V}$ dosud publikovaných studiích lze nalézt charakteristické typy zobrazení vhodné pro prezentaci kvality městského prostoru a stanovit tak, ke kterým $\mathrm{z}$ nich autoři nejvíce inklinují.

Jedni autoři (Mahmoudi, 2015) prezentovali článek, ve kterém hodnotili dvě různé ulice ve městě Kuala Lumpur. Výzkum je prezentován prostřednictvím fotodokumentace a tabulek. V jiné studii (Sauter, 2008) byly představeny výsledky studie ze Švýcarska, která zkoumala intenzitu sousedských vztahů v závislosti na rychlosti dopravy na ulicích. Výsledky byly předloženy především formou sloupcových grafů, doplněných výčtem výsledků v tabulce. Článek autorů Smithe, Nelischera a Perkinse (1997) prezentoval výsledky studie hledající souvislost mezi kvalitou veřejného prostranství a jeho fyzikální formou pouze pomocí tabulek. Jiní autoři (Ruiz-Apilánez, 2017) ve svém článku na téma bezpečnost ve veřejném prostoru ulic prezentovali výsledky výzkumu kromě fotografií a tabulek rovněž prostřednictvím mapových schémat se zakreslením pozorovaných jevů (tras chodců). V několika nalezených studiích (Vanderhaegen, 2017; Ruiz-Apilánez, 2017) bylo k zobrazení dat využito krabicového diagramu (boxplot).

Byt' byla data použitá $\mathrm{k}$ prezentaci v tomto prŕspěvku sesbírána na základě metodiky popsané Janem Gehlem (2013), její aplikace nebyla nikdy popsána pomocí žádných př́padových studií, které by byly publikovány ve vědeckých databázích. Proto je důležité stanovit správný postup zobrazení dat s ohledem na cílového čtenáře (vědecká komunita, představitelé měst, laická veřejnost). Tento článek prezentuje zobrazovací metody, které jsou vhodné k použití v disertační práci.

Cílem př́spěvku je stanovit vhodný způsob zobrazování dat o kvalitě veřejného prostoru tak, aby nebyl zavádějící a měl maximální výpovědní hodnotu. S tímto záměrem byly revidovány výsledky autorského výzkumu z roku 2014, které byly prezentovány v knize Moje náměstí (Kilnarová; Kopáčik, 2014).

\section{Zdrojová data}

Pro práci byla využita data získaná vlastním výzkumem typu a četnosti aktivit ve veřejném prostoru náměstí a jeho návštěvnosti. Tato data byla získávána ve zkoumaném prostoru po dobu 16 hodin od 7:00 do 23:00, a to ve všední den a jeden den víkendu. 
Každou hodinu byl zkoumaný prostor analyzován pozorovatelem a do předem připraveného záznamového archu s mapou náměstí, která zobrazuje hranice okolních budov a všechny ostatní mobiliářové prvky i hrany terénu vyskytující se na náměstí, byly zaznačeny všechny stacionární aktivity, které uživatelé v daný okamžik prováděli. Základním pravidlem přitom bylo započítat každého $\mathrm{z}$ uživatelů pouze jednou. Získaná informace se tedy skládá ze 3 faktů: umístění vykonávané aktivity, typ vykonávané aktivity, časový rámec. Rovněž byli počítáni všichni chodci, kteří vstoupili do prostoru náměstí. $\mathrm{Z}$ tohoto počtu pak bylo aritmetickým průměrem vypočítáno celkové množství návštěvníků náměstí v jednotlivých hodinách. Mimo to byl jednou za hodinu monitorován počet aut parkujících v prostoru náměstí a do slepé mapy byl zaznamenáván pohyb 100 náhodně vybraných chodců. (Gehl, 2013)

\section{Zkoumané lokality}

Jakubské náměstí leží na místě původního hřbitova přiléhajícího ke kostelu sv. Jakuba a je typickým př́kladem náměstí v historickém jádru města. Kostel sv. Jakuba je dominantou náměstí a uzavírá ho ze západní strany. Okolní budovy dosahují výšky okolo 4-5 podlaží a v jejich parteru jsou především restaurace. V horních patrech pak navazují kancelářské prostory, hotel, restaurační prostory, v malé míře je zastoupeno i bydlení. Náměstí je pěší zóna a plní především společenské funkce.

\section{Metodika výběru grafických výstupů}

K prezentaci výstupů lze použít grafického zobrazení pomocí map, grafů a tabulek. Každé z těchto zobrazení má svá úskalí, která mohou vést ke zkreslení prezentovaných výsledků - zobrazení totiž důkladně nezdůrazňují veškeré informace, které mohou výsledek ovlivnit. Naopak kombinací zobrazení lze výsledky s ohledem na všechny okrajové podmínky vyjádřit přesně.

Nejvíce ovlivňuje proces výběru příležitost, pro kterou se data prezentují. Jinak je možné data prezentovat $\mathrm{v}$ odborné publikaci, která dává autorovi více prostoru než např. vědecký článek, který by měl být vysoce odborný, a přitom stručný. Při orální prezentaci před publikem je možné využít multimediální techniky, která nabízí možnost použití videa, animace apod.

Dalším kritériem je povaha zobrazovaných dat, resp. to, zda se jedná o data kvalitativní, či kvantitativní a zda jsou podmíněna časem, nebo jsou souhrnná a obecně platná.

Rozhodovací proces jde vyjádřit diagramem na Obr. 1. 


\title{
Výsledná prezentace dat
}

\begin{abstract}
Aktivity
Prezentace vykonávaných aktivit zahrnuje poznatky o tom, kolik aktivit bylo v danou hodinu na náměstí vykonáváno, o jaký druh vykonávané aktivity se jedná (sezení, stání, venčení psa) a kde v prostoru se daná aktivita odehrávala. Pro prezentaci laické veřejnosti nebo na vědeckém sympoziu je možné sloučit všechny tyto atributy do jedné mapy, která využije obalových křivek ke znázornění intenzity zobrazovaného jevu a jeho polohy v prostoru. Toto zobrazení by zahrnovalo veškeré aktivity, jež se odehrávaly v pozorovaný den. Barevně by bylo možné odlišit druh vykonávané aktivity. Doplňkovým zobrazením by pak mohl být sloupcový graf, který by prezentoval druh a počet jednotlivých aktivit za každý interval pozorování (1 hodina). Pro potřeby prezentace, at už před publikem, či na internetu, by bylo možné vytvořit video, které je schopno zobrazit proměnu pozorovaného jevu v čase pozorování po hodinách.
\end{abstract}

\section{Četnost využití vstupů}

Jakubské náměstí má celkem 6 vstupů. Pro každý vstup existují data o počtu prríchozích za každou hodinu. Další informace uvádí celkový počet návštěvníků Jakubského náměstí za celý den. K prezentaci tohoto atributu je možné využít mapového schématu v kombinaci s koláčovým grafem, kterým bude vyjádřen poměr mezi počty návštěvníků využívajících jednotlivé vstupy a poměr mezi počty návštěvníků ve všední den a den víkendu. Výsledný koláčový graf bude vyjadřovat poměr celkového počtu návštěvníků za celý všední den k celkovému počtu návštěvníků za celý den o víkendu.

Zobrazení by dále mohlo být doplněno o další sledované informace, jako je počet vjíždějících cyklistů a automobilů.

\section{Trasování chodců}

Vzhledem k metodě jeho pořízení jsou zaznamenané výsledky velmi nepřesné - důvodem je to, že pozorovatel vybíral chodce náhodně. Takový výběr nelze považovat za výběr s obecnou vypovídací hodnotou. Tento atribut je však možné využít jako doplňkové zobrazení pro mapové schéma četnosti využití vstupů, nebo ve spojení s mapovým schématem parkování, kde může trasování poukázat na významnou bariéru, kterou tvoři parkovací plochy. Pokud by byla vyvinuta přesnější metodika výběru sledovaných chodců, mohlo by být zobrazení prezentováno samostatně, jako např́iklad v dříve zmiňovaném článku. (Ruiz-Apilánez, 2017) 


\section{Parkování}

Četnost parkujících aut v prostoru je vyjádřena spojnicovým grafem četnosti po hodinách. U parkujících aut je však významná poloha parkovacích ploch, a proto je znázorněna i v mapovém schématu prezentujícím využití jednotlivých ploch v prostoru náměstí.

\section{Vyhodnocení}

Z výše uvedeného lze vyvodit, že pro různé typy prezentace výsledkủ je vhodné použít různé metody zobrazení.

Výsledná prezentace informací pomocí mapových schémat je vhodná pro svou přehlednost, i když není možné znázornit porovnání těchto dat $\mathrm{v}$ čase. Využití grafu se jeví jako užitečné při prezentaci ve vědeckém článku, ale už není tolik přehledné pro širokou laickou a odbornou veřejnost. $\mathrm{V}$ disertační práci proto bude pro každý zkoumaný atribut využito kombinace mapových schémat a grafư. Dále by bylo vhodné prezentovat výsledky za pomoci webové aplikace využívající GIS, která umožňuje podrobnější prezentaci zobrazených informací, a bylo by možné všechny charakteristiky sloučit do jedné mapy. Např́ílad by bylo zajímavé sledovat, jak se místa odehrávajících se aktivit posouvají vzhledem ke slunci a stínu, a pomocí obalových křivek identifikovat nejvytíženější části náměstí a dále zkoumat, čím jsou pro návštěvníky tak zajímavé. Př́nosné by bylo znázornění proměny náplně aktivit vzhledem $\mathrm{k}$ denní době a také vývoje těchto aktivit $v$ průběhu kalendářního nebo akademického roku.

Dalším směrem, kam by se prezentace dat dala posunout, je zanesení statistických dat do prezentace výsledků - porovnání s počtem obyvatel městské části nebo okolních domů, docházkové vzdálenosti od jiných významných veřejných prostranství (náměstí, parků) apod.

Příspěvek vznikl ve vazbě na výzkumný projekt FA-S-16-3727 - 100. výročí vzdělávání architektů na Fakultě architektury VUT v Brně, oblast urbanismus.

\section{Prameny}

GEHL, Jan a Birgitte SVARRE, 2013. How to study public life. London: Island Press. ISBN 16-109-1423-6.

KILNAROVÁ, Pavla, Ivana LELKES, Kristián ŠKODA, Michal VESELÝ a Shorouk 
TOUCHAN, KOPÁČIK, Gabriel, Evgeniia KUZNETCOVA a Jana ZDRAŽILOVÁ, ed., 2014. Moje náměstí. Brno: Akademické nakladatelství CERM. ISBN 97880-7204-894-6.

MAHMOUDI, Mohadeseh, Faizah AHMAD a Bushra ABBASI, 2015. Livable streets: The effects of physical problems on the quality and livability of Kuala Lumpur streets. Cities. 43, 104-114. DOI: 10.1016/j.cities.2014.11.016. ISSN 02642751. Dostupné také z: http://linkinghub.elsevier.com/retrieve/pii/S0264275114002017

RUIZ-APILÁNEZ, Borja, Kayvan KARIMI, Irene GARCÍA-CAMACHA a Raúl MARTÍN, 2017. Shared space streets: design, user perception and performance. URBAN DESIGN International. 22(3), 267-284. DOI: 10.1057/s41289-016-0036-

2. ISSN 1357-5317. Dostupné také z: http://link.springer.com/10.1057/s41289016-0036-2

SAUTER, Daniel a Marco HUETTENMOSER, 2008. Liveable streets and social inclusion. URBAN DESIGN International. 13(2), 67-79. DOI: 10.1057/ udi.2008.15. ISSN 1357-5317. Dostupné také z: http://link.springer.com/10.1057/ udi. 2008.15

VANDERHAEGEN, Sven a Frank CANTERS, 2017. Mapping urban form and function at city block level using spatial metrics. Landscape and Urban Planning. 167, 399-409. DOI: 10.1016/j.landurbplan.2017.05.023. ISSN 01692046. Dostupné také z: http://linkinghub.elsevier.com/retrieve/pii/S0169204617301275

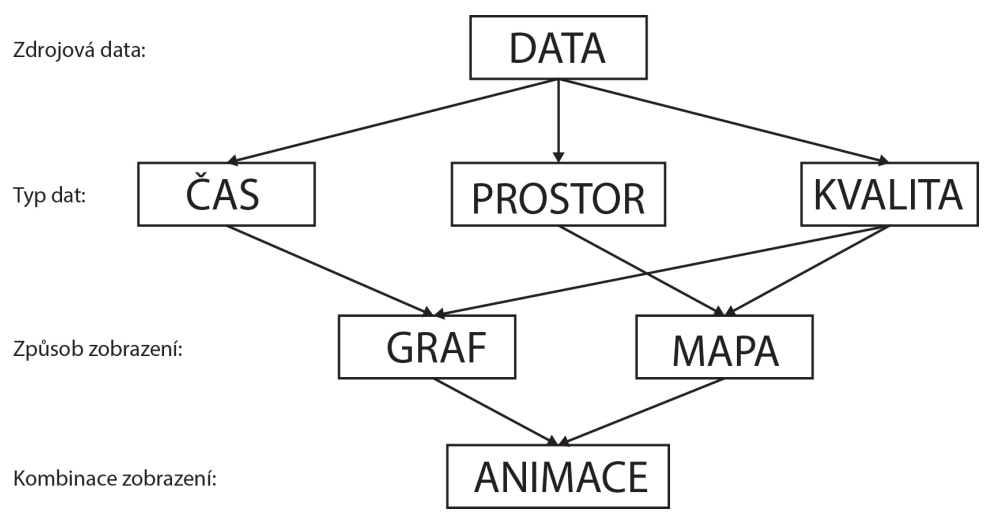

Obr. 1. Vývojový diagram rozhodovacího procesu při volbě zobrazovací metody (Zdroj: archiv autora) 


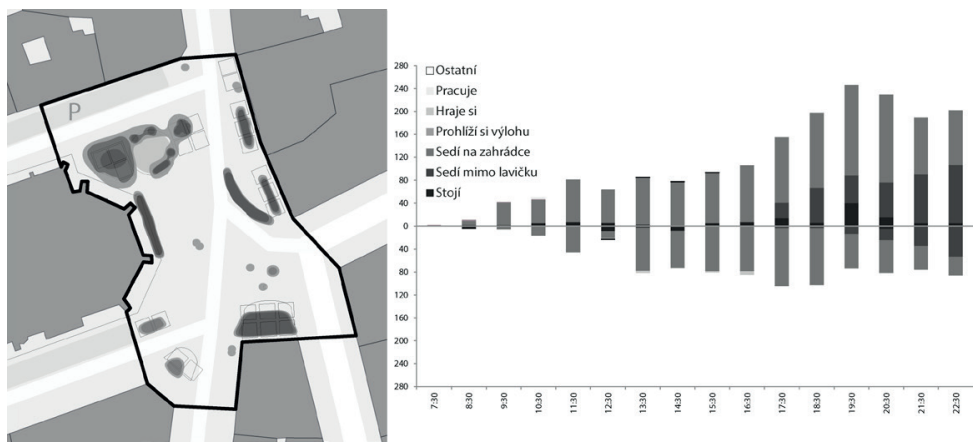

Obr. 2. Prezentace aktivit pozorovaných na Jakubském náměstí pomocí mapového schématu a grafu. (Zdroj: archiv autora)

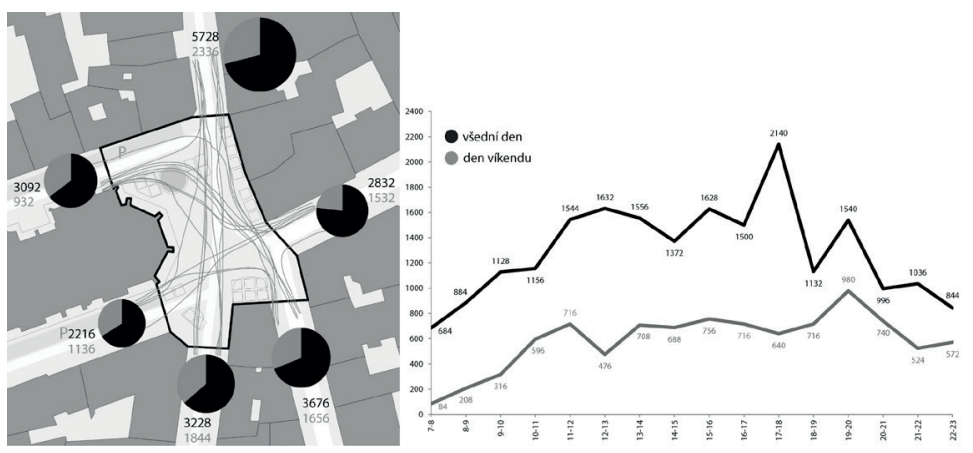

Obr. 3. Mapové schéma četnosti využití vstupů ve spojení s nejběžnějšími trasami procházejících chodců (Zdroj: archiv autora)
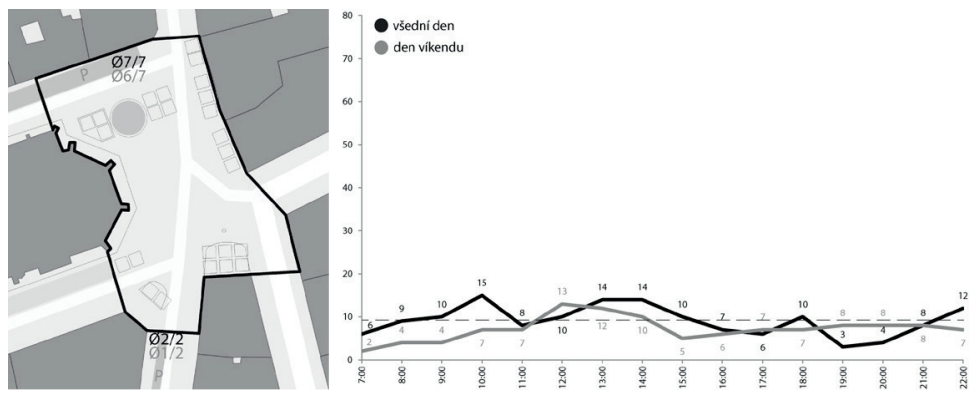

Obr. 4. Mapové schéma polohy parkovacích ploch se znázorněním četnosti jejich využití a graf počtu parkujících aut v prostoru po hodinách. (Zdroj: archiv autora) 